\title{
Optimizing Protection of Geographical Indications in Indonesia by Special State Agency
}

\author{
Mieke Yustia Ayu Ratna Sari ${ }^{1 *}$ I Nyoman Nurjaya ${ }^{2} \quad$ Yuliati $^{2} \quad$ Bambang Winarno $^{2}$ \\ 1.Faculty of Law Brawijaya University and Faculty of Law Tulang Bawang University, Indonesia \\ 2.Faculty of Law Brawijaya University, Indonesia
}

\begin{abstract}
This study aims at analysing special state agency in order to optimize the protection of geographical indications. The agency plays crucial role in supervising the use of geographical product. The protection of geographical indications in France has been well-developed because it is not only supported by comprehensive regulation but also by special agency called INAO which is based on special regulation formulated by European Community Countries to protect product trademark including AOC/PDO and PGI. INAO is an independent public organization which is controlled by citizen and work together with professional organization in wine beverage industries and food product and it is supported by National Committee chaired by professionals. Indonesia with its natural resources should be protected as geographical indications. Therefore, there must be special state agency for comprehensive and optimum protection. This study employs normative method and comparative approach to France.
\end{abstract}

Keywords: geographical indications, INAO, French, TRIP's agreement

DOI: $10.7176 / J L P G / 82-10$

\section{Introduction}

Concept of Intellectual property developed in western countries; furthermore it has been part of local culture that is formalized into legislation. Intellectual property as part of law in Indonesia was first developed based on the law composed during Dutch colonization and it was valid by applying concordance principle. There were only three types of Intellectual property namely Copyright, Patent right, and Trademark. After declaring its independence, legislations on Intellectual property had gradually been invalid and they are replaced by special legislation on Intellectual property based on their regime. For instance, Copyright Auteurswet Stb No.600 of 1912 was declared to be invalid after releasing Law no 6 of 1982 on Copyright. For copyright, Octrooi wet No 313 of 1910 was withdrawn and replaced by Law no 6 of 1989 on Patent right. For Trademark, Reglement Industriele Eigendom No. 545 of 1912 was replaced by Law No 21 of 1961 on Trademark ${ }^{1}$.

The scope of Intellectual property in Indonesia which initially consisted of three regimes has expanded to include Industrial Design, integrated circuits, neighbouring right (covered in Copyright), geographical indications right, and Trade Secret after the ratification of TRIP's Agreement. The ratification of TRIP's agreement through Law No 7 of 1995 on the declaration of Agreement on Establishment of The World Trade Organization influences the existing regulation. All legislations on Intellectual Property have been revised in order to keep up with TRIP's Agreement because Indonesia is the member of WTO. The revision is on Copyright under the law no 7 of 1987 on Amendment of Law no 6 of 1982 on Copyright and it is replaced by Law no 12 of 1997 on The Amendment of Law No 6 of 1982 on Copyright which is replaced by Law no 7 of 1987. Regulation on copyright has undergone several changes. For instance, in 2002, Copyright Law was replaced by Law no 190 of 2002 and then it was also replaced by Law no 28 of 2014 on Copyright.

Legal framework for Patent right has been revised in which the law no 13 of 1997 on The Amendment of Law no 6 of 1989 on Patent right has been replaced by Law No 14 of 2001. It was due to harmonization with TRIP's Agreement in order to provide protection for investor and to create clean business competition atmosphere 2 . atmosphere $^{2}$. In 2016, legal framework for patent was replaced by Law No 13 of 2016 to improve protection for investors and patent right holder and to encourage investor to improve their works for national prosperity ${ }^{3}$.

For trademark domain, the adjustment to TRIP's Agreement through Law No 19 of 1982 on Trademark has been changed into Law No 14 of 1997 on The Amendment of Law No 19 of 1992 on Trademark. Lastly, it was replaced by Law no 20 of 2016 on Trademark and geographical indications. Concerning the last adjustment, geographical indications has been put into the law because together with trademark, they are of different regimes composed in a single law; therefore, the two must be clearly stated to clarify the content of the law.

After TRIP's Agreement, Indonesia as member of WTO composes legal framework for Intellectual Property in addition to copyright, patent and trademark. The effort is in line with Part II of TRIP's Agreement on Standard of Availability, Scope and Use of Intellectual Property Right which consist of copyright and related right,

\footnotetext{
${ }^{1}$ OK. Saidin. (1995). Aspek Hukum Hak Kekayaan Intelektual. (Cetakan ke 9). Jakarta : PT. RajaGrafindo Persada. p. 21

2 The phrase "considering" of Law no 14 of 2001 on Patent

${ }^{3}$ The phare "considering" of Law no 13 of 2016 on Patent
} 
trademark, geographical indications, industrial design, patent, layout design (topography) of integrated circuit, protection of undisclosed information and control of anti competitive business. On 2000, Indonesia formulated three legal frameworks for Intellectual Property namely law no 31 of 2000 on Industrial Design, Law no 30 of 200 on Trade Secret and Law no 32 of 2000 on Layout Design of Integrated Circuit.

Geographical indications is one of the regimes of Intellectual Rights which initially developed in France and was known as Indication of Sources and Indication of Origin. As developed countries, France are well-known for its sophisticated and fixed protection of geographical indications. It was due to their history of the origin of geographical indications protection in France which was started when they provide protection for Requefort cheese in 1411 by granting Protection Charter of Appellation of Origin. It was starting point and crucial momentum to compose comprehensive legal framework included in national legislation and international treaty. Protection of geographical indications in France are not only supported by comprehensive regulation but also by special agency with special duty to protect and supervise the development and use of geographical product. The agency, the so called I'institut Nationale des Appellation d'Origins (INAO) is controlled by public and works together with professionals in the field of wine, daily diet and food product.

In Indonesia, legal framework development of geographical indications was rooted on National Law no 14 of 1997 on the Amendment of Law No 19 of 1992 on trademark. Points on geographical indications are only stated in 3 articles namely article no 79A, 79B and 79C regulating the scope, protection, law suit, and requirements on investigating officer. The arrangement of geographical indications in Law on Trademark has not changed although it has been replaced by Law no 15 of 2001. Geographical indications and trademark are integrated in a single law because the law makers believe that geographical indications is type of trademark protection based on location specifications which are influenced by geographical factor ${ }^{1}$. The perspective is still maintained up to now although Law on Trademarks has changed three times ${ }^{2}$. Significant difference on arrangement of geographical indications is reflected on new legislation namely law no 20 of 2016 on Trademark and geographical indications. On the new legislation, there are 17 articles on geographical indications stated in 5 chapters.

The afore-mentioned description shows that there has been crucial development on the arrangement of Geographical Indication; however it doesn't give direct impact on the protection of Geographical Indication either before or after product registration. Thus Indonesia should learn from France about the protection of Geographical Indication. Based on the existing facts, the writer formulates the research problem on the significance of national agency to optimize Geographical Indication protection in Indonesia

\section{Method}

This is normative law study to solve problems in order to obtain coherence truth based on moral benchmark. Prevailing norms in the forms of behavioural guidance should be based on legal principles based on moral value. Therefore, this study results in coherence prescription with legal framework which is based on moral value. ${ }^{3}$

This study focuses on the protection of Geographical Indication by special national agency, by employing comparative approach in which the writer compares protection of Geographical Indication in Indonesia to that of in France having comprehensive Geographical Indication protection in the form of existing regulations or its national agency. The method requires the writer to study regulations on Geographical Indication protection in France. Law materials that have been gathered are identified, sorted and selected based on pre determined research problem.

\section{Analysis and Discussion}

France is one of developed countries having sophisticated and fixed protection of Geographical Indication. Source indications only reveals geographical origin of the products and do not influence their quality, appellation origin (appellation d'origine) is regulated under Law on Protection of Appellation Origin dated at 6 May 1919 and it is intended for products whose characteristics qualities are related to geographical factors; and Geographical Indication (indications geographique) stated in Law no 3 of January 1994 on The Acknowledgement of Farming Product and Food Material Quality. Geographical Indication is used as general term covering sources indications and appellation origin. On TRIP's Agreement, the term is defined more specifically among the other two categories. It is more than source indications but it doesn't have to fulfil high quality standard as required for appellation origin. ${ }^{4}$

France has various superior products which are influenced by geographical factors such as "Roquefort" (cheese), "Kobe" (cow), "scotch" (whiskey) and "wine". Those products are protected. Especially for wine, France adopted law giving exclusive right for producers of local wine to designate wine name representing type

\footnotetext{
${ }^{1}$ Ministry of Law and Human Right of Indonesia, (2015), Academic Papers on Legislation Draf on Trademark, Jakarta, p. 7

${ }^{2}$ First, Law No 14 of 1997 on the amendment of Law no 19 of 1991 on Trademark. Secondly, Law no 15 of 2001 on trademark. Thirdly, Law no 20 of 2016 on Trademark and Geographical Indication.

${ }^{3}$ Peter Mahmud Marzuki (2015). Penelitian Hukum (edisi revisi). Jakarta. Prenedamedia Group, p 64

${ }^{4}$ Bernard O’Connor, (2004), The Law of Geographical Indication, Britain : Cameron May Ltd, p. 165
} 
and quality of product. Champagne and Bordeaux are famous example for that. Law system in France requires the protection of Wine through appellation system by fulfilling several criteria such as quality, types (characteristic quality of wine representing the uniqueness of certain area or certain wine variety), geographical factors and production method. ${ }^{1}$

Since July $1^{\text {st }} 1995$, Appellations of Origin (AO) has changed into Controlled Appellation of Origin (AOC) except high quality wine and list of origin name from Ministry of Foreign Affair of France maintaining previous status. AOC protects products controlled by the state to ensure the originality of source region, the conformity of production standard, the process which is in line with "typicity" and certain unique character. AOC label is acknowledged in European Union. AOC supports Geographical Indication as starting point to develop new farming system based on unique values of origin region. For AOC, natural factors are determinant factors for product quality showing terroir, especially natural quality of certain region (land, micro climate, slope, exposure and others), in addition, it is also the integration of natural and human factors. ${ }^{2}$

The protection of Geographical Indication in France national law is the form of law harmonization of European Union in addition to several ratification of multilateral agreement. Basically, the protection of Geographical Indication in France is such a complicated matter aiming at protecting Appellation of Origin (AOC) so that registered group of producer in certain area has a right to use name and resources of the region to obtain economic benefit. Other benefit for having right of Appellation of Origin is protection from competitors from the same region of product and from the passing-off reputation. Type of protection for Appellation-of-Origin based Geographical Indication in France is a second level protection emphasizing on producers interest as stated in article 23 of TRIP's agreement on Additional Protection for Wine and Spirits. ${ }^{3}$ Appellation of Origin protection in France is granted provided that certain requirements are fulfilled such as good reputation of product; its relation between geographical origin and product character; acknowledgement of product name by court decree or other administrative legislation; and registration of product name on State Agency of Appellation of Origin or I'institut Nationale des Appellation d'Origins (INAO).

INAO is special national agency in France which is authorized to designate area of origin ${ }^{4}$ or Geographical Indication $^{5}$. It is public and independent agency controlled by citizen and professional organization of wine and food product and it is supported by National Committee whose members are professional. INAO is located in Montreuil, eastern part Frech, 6, $6 \mathrm{~km}$ (4,1 mile) from Paris. There are 8 branch offices in French with 250 agents whose responsibility is to support producers to obtain certificate of designation of origin. The agents prepares and implements the decision of INAO upon product registration and then, they monitor the producers during product usage to control, protect the origin and area, and to protect the registered trademark and to promote international cooperation on registered product. ${ }^{6}$

Job and responsibility of INAO covers pre and post protection of product such as to control and test each product that has been classified into designation of origin, to register and give protection, to monitor the implementation of geographical product usage, to give area label and to protect the appellation of Origin and Geographical Indication, to monitor the examination system of designation of origin, and to ensure that all people and stakeholder get information on policies on designation of origin (AOC/PDO, PGI). INAO monitors more than 70 brand of wine which are protected using PDO, and more than hundred of farming product which are protected by PGI and also monitor more than 400 compulsory specification for product of "label rouge". 7

Legislations functioning as the basis for INAO to obey requirements of product designation protection prevailing in European Union are AOC/PDO and PGI. IG protection (PGI) for food is regulated in Parliamentary Legislation (European Union) no 1151/2012 on the Quality scheme for farming product and food materials and Commission Legislation (European Union) No 668/2014 of 13 June 2014 stating detail rule to implement the legislation (European Union) no 1151/2012 of European Parliament and Board on quality scheme for farming product and food materials. IG protection (PGI) for wine is defined in Legislation (European Union) no 1308/2013 on the organization of general marketplace for farming product (wine product). IG legislation for spirits is legislation (EC) no 110/2008 of European parliament and board of 15 January 2018 on definition, description, display, labelling and protection of IG for spirits and it cancels the rule (EEC) no 1576/1989.

Concerning the existence of INAO in France with their comprehensive working scope, it is believed that products that are registered for designation of origin will be protected and supported so the products are able to

\footnotetext{
${ }^{1}$ Raz Barnea, Appellation and Adaptations : Geographical Indications, Viticulture and Climate Change, Washington International Law Journal, Volume 26 No. 3, p. 605.

${ }^{2}$ Elizabeth Barham, (2003), Translating Terroir : The Global Challenge of French AOC Labelling. Journal of Rural Studies. Vol. 19. p. 135

${ }^{3}$ Miranda Risang Ayu, (2006), Memperbincangkan Hak Kekayaan Intelektual : Indikasi Geografis, Bandung : PT. Alumni, p. 107.

${ }^{4}$ In France, it is called Controlled Appellation of Origin (AOC), protected designation of Origin), Protected Geographical Indication.

${ }^{5}$ France applies labelling system for food and farming product emphasizing on their origin namely AOC (appellation d'origin) exploring two aspects related to local factor through terroir concept and global aspect as intellectual right as declared by WTO, namely Geographical Indication

${ }^{6}$ www.inao.gouv.fr

7 ibid
} 
develop as superior products which are profitable and are able to improve the prosperity of producers or right holder of designation of origin. Based on the nature of agency, Indonesia also has special agency for registering Geographical Indication namely Directorate of Trademark and Geographical Indication affair under Directorate of Intellectual Property of Ministry of Law and Human Right. The two agencies are responsible for registering Geographical Indication. However, they are different because INAO is public independent agency which are controlled by people, meaning that people may give contribution and it has fixed working system from preparing product up to commercializing them to international level. In Indonesia, it is central and regional government having authority to manage and monitor Geographical Indication.

On November $25^{\text {th }} 2016$, Indonesia released new legislation on Geographical Indication namely Law no 21 of 2016 on Trademark and Geographical Indication. Viewed from its history, regulation on intellectual property has taken the development of international law into account; therefore, legal system and management is in accordance with international convention. However, the law is still rooted on our legal principle which is Pancasila. During its formulation, the law has also taken people's aspiration which are represented by various experts, creative industry businessmen, and other related stakeholders into account. The description of Geographical Indication in the new law shows more significant improvement than that of previous law in which it is only stated in 3 articles. In addition, requirements that should be stated in the law are put in government regulation no 51 of 2007 on Geographical Indication. Law no 20 of 2016 regulates Geographical Indication more comprehensively covering its law protection. There are 17 articles which are divided into 5 chapters. On article 53, 54, and 55 of Chapter VIII on Geographical Indication, there are regulation on applicant and application of Geographical Indication. Chapter IX on IG registration provides details on Geographical Indication that cannot be registered and rejected and they are stated in article 56 and 57. Chapter 58, 59 and 60 explains about substantive examination and protection term and deletion of Geographical Indication are stated in article 61 and 62. Chapter X on the violation and lawsuit defines the violation of Geographical Indication in article 66, lawsuit in article 67 and 68. Chapter XI is about management and supervision of Geographical Indication in which management aspect is stated in article 70 , supervision in article 71. Chapter XIII on documentation networking system and trademark information and Geographical Indication states the detail of regulation in article 80 and 81 .

Especially for management stated in article 70, there several stages that should be conducted. The stages are preparation stage to fulfil application requirements; registration application; the use and geographical indicated product commercialization; mapping and inventory of product potentials; training and partnership; monitoring, evaluating and managing aspects; law protection; and development facilities; processing and marketing geographical-indicated product. The supervision of Geographical Indication is conducted to ensure the protection of reputation, quality, and characteristics which are the basis for formulation of Geographical Indication regulation and also to prevent misuse of Geographical Indication as stated in article no 71. Central and regional government are responsible for the supervision as stated in prevailing regulation.

Although in Indonesia, there has not been special agency in charge of Geographical Indication, there is an independent team whose job responsibilities covers pre and post product registration, namely Expert Team of Geographical Indication. Based on article no 58 and 59 of Law no 20 of 2016 on trademark and Geographical Indication, the responsibilities of expert team of Geographical Indication is to conduct substantive examination covering assessment of documents of Geographical Indication and giving recommendation to related Ministry on registration, revision, cancellation and/or supervision of Geographical Indication. Task and main function of Geographical Indication team supported by assessment technical team are crucial. They are started from registration process up to supervision of Geographical Indication implementation to conduct periodical examination on quality assurance or product character that has been protected by Geographical Indication regulation. Non conformity found should be reported to General Directorate of Intellectual Property and followed up by releasing decree of rejection of Geographical Indication or cancelling the certificate if product quality do not fulfil the stated requirement. ${ }^{1}$ The responsibilities of expert team of Geographical Indication are so complicated; however the number of personnel of the team are not adequate. In article 59 verse 2 of Law no 20 of 2016, it is stated that maximum number of expert team member is 15 persons consisting of the representatives from related Ministry; representative from Ministry of Farming, Industry, Trade affair and/or other related ministry; representatives from agency authorized to supervise and/or test product quality. In essence, the task of expert team is to ensure quality of pre and post registration of product. However, their task do not cover commercializing product.

In the new law, Geographical Indication has been regulated more comprehensively than the previous one and it gives significant influence on the number of registered products. Up to July 2018, Geographical Indications registered in General Directorate of Intellectual Property are 61 domestic products and 6 foreign products. The highest number of commodities that has been registered is coffee. There are 24 types of coffee such as Kintamani

\footnotetext{
${ }^{1}$ Mas Rahmah, (2017), Hak Milik Industri Perlindungan Indikasi Geografis Untuk Produk Pertanian : Skenario Untuk Mendukung Ketahanan Pangan, Papers on International Conference "Symphonizing Intellectual Property and Potencial Resources for Public Welfare", Lombok : Law Faculty of Mataram University, p. 106.
} 
Bali, Arabica Gayo, Robusta Lampung, Robusta Semendo and others. Other registered product is spice such as Moluccas clove of Kie Raha, tomandin nutmeg of Fak Fak, cinnamon of Koerinthi, nutmeg of Siau, and others. There are also some Handicraft and industrial products that have been registered (gringsing weaving of Bali, silk weaving of Mandar, tied weaving of Sikka and Tanimbar. ${ }^{1}$

At present, General Directorate of Intellectual Property has declared "Geographical Indication Year". Branch office of Ministry of Law and Human Right in each region should register one product with Geographical Indication potentials and inventorying communal wealth in their region. ${ }^{2}$ Data collection of community intellectual property is conducted to protect biological and cultural diversity covering genetics resources, traditional knowledge, traditional cultural expressions and Geographical Indication. The data collection also aims at preventing claim, stealing and pirating conducted by other countries. National data centre of community Intellectual Property is to strengthen sovereignty, proprietary right of community intellectual property and to prevent foreign countries to claim our intellectual right. Community intellectual property is part of national identity and national asset that should be protected, developed, promoted and used at local, national or international level. ${ }^{3}$

Collecting and registering community intellectual property aims at protecting, encouraging active participation of regional government to update data on traditional culture in their region, providing easy and fast data access and information on traditional cultural expression to be used positively. ${ }^{4}$ Presently, there are two agencies who are in charge for that, namely General Directorate of Intellectual Right and Ministry of Culture and Education. There are slight difference on the object that will be recorded. General Directorate of Intellectual Property collected data on community intellectual property covering traditional culture expression, traditional knowledge, potential of Geographical Indication and genetics resources and Ministry of Education is responsible for collecting data on intangible cultural heritage $\mathrm{e}^{5}$ in each province.

The essence of Geographical Indication protection do not cover registration stage only but also commercializing product stage after obtaining certificate. In Indonesia, the right holders such as agency representing community and provincial and/or regional government are responsible for commercializing products. Indonesia doesn't have special agency for protecting Geographical Indication comprehensively as that in France. Therefore, pre and post registration activities are responsibilities of right holders or regional government in which the products are registered. It is factor that inhibit the number of registered products in each area.

Geographical Indication should be protected by law because firstly, Geographical Indication is designation sign of product from certain area or name of product produced in certain region and it cannot be used for product from other region. Secondly, Geographical Indication is quality indicator showing to customer that the product of certain area in which certain natural aspects result in certain characteristics of product. Thirdly, it is also one of the business strategies resulting in added value of product due to its originality and product limitation that cannot be produced in other places. Fourthly, based on TRIP's agreement, Geographical Indication is part of intellectual property whose proprietary right might be maintained from every violation and illegal competition. ${ }^{6}$ Geographical Indication protection gives positive impacts for people and the region, therefore there should be special agency which is in charge of Geographical Indication protection to optimize protection efforts.

Indonesia has great natural resources with biological diversity in each province, region or area. Each area has superior product which is geographically-indicated. Based on Geographical Indication product registered on General Directorate of Intellectual Property, there may be more than one product from one province. For instance, Lampung has 2 products namely black pepper and Robusta Coffee, in Yogyakarta there are two regions with special products which are Coconut sugar of Kulonprogo and Salak Pondoh from Sleman. The afore-mentioned examples are proofs that each area has great potentials of geographically-indicated product. The potentials should be followed by law protection, management system, and supervision by special agency to protect all geographically-indicated product from product registration up to commercialization. It is the proof that Geographical Indication gives significant impact for all stakeholders especially the surrounding people. The existence of special national agency in charge of Geographical Indication is important to optimize the protection of Geographical Indication from product registration up to commercialization.

\section{Conclusion}

In order to obtain maximum benefit of Geographical Indication, there should be comprehensive protection from pre and post registration. France has special agency which is in charge of protecting products with designation of origin namely INAO. In Indonesia, based on article 70 and 71 of Law no 20 0f 2016 on trademark and Geographical

\footnotetext{
${ }^{1}$ http://www.dgip.go.id

${ }^{2}$ http://www.dgip.go.id

${ }^{3}$ www.kabar24.bisnis.com

${ }^{4}$ http://www.dgip.go.id

${ }^{5}$ Convention for the safeguard of the intangible cultural heritange memberikan definisi tentang Warisan Budaya Takbenda Pasal 2 ayat (1) :

"the practices, representations, expressions, knowledge, skills -as well as the instruments, objects, artefacts and cultural spaces associated therewith -that communities, groups and, in some cases, individuals rerognize as part of their cultural heritage".

${ }^{6}$ Saky Septiono, Protection of Geographical Indication and Potentials of Geographical Indication indication in Indonesia http://www.dgip.go.id
} 
Indication, supervision and management are the responsibilities of Central and Regional government as stated in prevailing regulation. Its cope of activities is so broad that if central government does not take it seriously, the Geographical Indication protection might not be evenly distributed. Therefore, there must be special independent agency which is in charge of Geographical Indication protection.

\section{References}

Bernard O’Connor, (2004), The Law of Geographical Indication, Britain : Cameron May Ltd

Mas Rahmah, (2017), Hak Milik Industri Perlindungan Indikasi Geografis Untuk Produk Pertanian : Skenario Untuk Mendukung Ketahanan Pangan, Paper in International Conference "Symphonizing Intellectual Property and Potencial Resources for Public Welfare", Lombok : Fakultas Hukum Universitas Mataram

Miranda Risang Ayu, (2006), Memperbincangkan Hak Kekayaan Intelektual : Indikasi Geografis, Bandung : PT. Alumni

OK. Saidin. (1995). Aspek Hukum Hak Kekayaan Intelektual. (Cetakan ke 9). Jakarta : PT. RajaGrafindo Persada Peter Mahmud Marzuki. (2015). Penelitian Hukum (Edisi Revisi). Jakarta : Prenedamedia Group

Ministry of Law and Human Right of Indonesia, (2015), Academic Papers on Legislation Draf on Trademark, Jakarta

Elizabeth Barham, (2003), Translating Terroir : The Global Challenge of French AOC Labelling. Journal of Rural Studies. Vol. 19

Raz Barnea, Appellation and Adaptations : Geographical Indications, Viticulture and Climate Change, Washington International Law Journal, Volume 26 No. 3

Law No. 14 of 2001 on Patent

Law No. 13 tahun 2016 on Patent

Saky Septiono, Protection of Geographical Indication and Potentials of Geographical Indication indication in Indonesia http://www.dgip.go.id

www.inao.gouv.fr

www.kabar24.bisnis.com

http://www.dgip.go.id 